Correction: Pre-existing inflammatory immune

microenvironment predicts the clinical response of vulvar

high-grade squamous intraepithelial lesions to therapeutic

\title{
HPV16 vaccination
}

Abdulrahman Z, de Miranda N, van Esch EMG, et al. Pre-existing inflammatory immune microenvironment predicts the clinical response of vulvar high-grade squamous intraepithelial lesions to therapeutic HPV16 vaccination. J ImmunoTher Cancer 2020;8:e000563. doi: 10.1136/jitc-2020-000563

In this article, authors Mariette I.E. van Poelgeest and Sjoerd H. van der Burg share last authorship.

Open access This is an open access article distributed in accordance with the Creative Commons Attribution Non Commercial (CC BY-NC 4.0) license, which permits others to distribute, remix, adapt, build upon this work non-commercially, and license their derivative works on different terms, provided the original work is properly cited, appropriate credit is given, any changes made indicated, and the use is non-commercial. See http://creativecommons.org/licenses/by-nc/4.0/.

(C) Author(s) (or their employer(s)) 2020. Re-use permitted under CC BY-NC. No commercial re-use. See rights and permissions. Published by BMJ.

J Immunother Cancer 2020;8:e000563corr1 . doi:10.1136/jitc-2020-000563corr1

A Check for updates 